\title{
VERSLAG VAN EEN REIS NAAR DEN HENDRIKTOP (BOVEN-SARAMACCA) \\ DOOR
}

J. W. GONGGRIJP EN GEROLD STAHEL

\section{III}

Maandag 20 Maart. Het geheele gezelschap is weer bij elkaar. De zieken, waarvan wij de laatste dagen nog al last hadden, zijn hersteld en wij laten met alle mannen vrachten naar K.M. 7. Wij zelf gaan na nogmaals bij de gevelde chicle-boomen te hebben gebotaniseerd, naar het uitzicht op den Hendriktop, waarvan wij nu een paar goede foto's kunnen maken.

Op de heuvels hier in de buurt komt dikwijls in groote hoeveelheden in het onderhout een prachtige stamlooze palm voor, de zoogenaamde Moeroe-moeroe (Acrocomia sclerocarpa?), met geweldige 7 tot $8 \mathrm{M}$. lange bladeren en groote schutbladeren. Een onzer is zoo verrukt over deze plant, dat hij met alle geweld bijna een geheelen palm bij het herbarium-materiaal wil voegen, niet in aanmerking nemende, dat wij al zooveel vracht voor de dragers hebben, dat deze zich tot het uiterste zullen moeten inspannen. De andere, nuchterder aangelegd, verzet zich hiertegen en wij krijgen een diepgaand meeningsverschil, dat pas weer wordt bijgelegd, als wij dicht bij het uitzicht op den Hendriktop verscheidene Hevea's vinden, waarvan alle bladeren de typische gaatjes vertoonen van de Zuid-Amerikaansche Hevea-bladziekte, die de rubbercultuur in Suriname onmogelijk heeft gemaakt. Dat deze Hevea's inderdaad door den zelfden schimmel waren aangetast, kon echter niet met zekerheid worden uitgemaakt, daar wij geen vruchtlichamen konden vinden.

Dinsdag 21 Maart. Verhuisdag naar den waterkant. 
Wij hebben een tocht van 16 K.M. voor den boeg, door gedeeltelijk zeer moeilijk terrein en, moge deze dagmarsch voor Europa belachelijk klein schijnen, in deze omstandigheden, langs het smalle paadje, over glibberige hellingen, omgevallen boomen en door moerassen, is deze weg reeds voor óns, alleen belast met een geweer en enkele instrumenten, zeer vermoeiend, zooveel te meer voor de zwaarbepakte arbeiders, die beladen met hun draagkorf (moetété) van minstens 30 K.G., met langzamen vasten stap en steunend op een langen stok gewillig voortzwoegen.

In het kamp bij K.M. 7.6 houden wij een oogenblik halt en verdeelen de vrachten, die daar liggen in eenmanslasten. Om kwart over vieren zijn wij aan den waterkant. Onderweg raken wij een oogenblik midden in een groote kudde pingo's (boschvarkens). De dieren maken een geweldig kabaal, door tandenknarsen, knorren en het vertrappen van struikgewas en doode takken, en schijnen ons in het geheel niet op te merken. Wij zien er wel tien tot twaalf stuks tegelijk rondom de lijken van twee hunner kameraden, die door Zaandam, die niettegenstaande zijn zware vracht is vooruitgeloopen, zijn geschoten. Anderhalve K.M. van het kamp komen wij hem tegen, hij heeft zijn vracht al naar het eindpunt gebracht en keert nu vier kilometers terug, om de beide pingos te bergen. Korten tijd na ons komt Dalger in het kamp met, behalve zijn vracht, nog een deel van de vracht van Tos, op zijn rug. Tos heeft zijn overige bagage onderweg laten liggen en is teruggeloopen met Zaandam, om hem met zijn varkens te helpen. Juist tegen donker komen Zaandam en Tos in het kamp aan, met àl hun vracht en àl het vleesch van de beide werkelijk niet lichte dieren.

Allen zijn nu aan den waterkant, behalve een man, Duits, die nog steeds op zich laat wachten. Het wordt donker en nog steeds geen spoor van Duits. Wij maken ons eenigszins ongerust en overwegen of het niet noodig is hem met een lantaarn langs den weg te gaan zoeken, maar bij nader inzien wordt het 't waarschijnlijkst geacht, dat hij, bemerkende het kamp aan den waterkant niet vóór donker te kunnen halen, zijn hangmat opge- 
hangen heeft in een afdakje bij K.M. 4, dat vroeger bij het vrachten in gebruik was. Maar tegen 7 uur, het is pikdonker in het bosch, en wij liggen reeds lang in de hangmat, zien wij tot onze groote verbazing een licht uit de duisternis naderen; en daar komt waarlijk, tot aller verbazing Duits aangestrompeld. Hij had toevallig een lantaarn bij zijn vracht en heeft deze aangestoken, om aldus nog den waterkant te kunnen bereiken. Door een vervelling aan zijn voet had hij niet vlugger kunnen loopen.

Het is hier zeker de plaats om een hartelijk woord van waardeering te spreken voor onze mannen, die getoond hebben, dat zij zonder morren tot een werkelijk buitengewone inspanning in staat zijn.

Woensdag 22 Maart. Toen wij gisteren aankwamen was de Tawa-kreek door de zware regens van twee dagen te voren nog sterk gezwollen, het terrasvormige terrein voor het kamp was geheel onder water en van onze booten zagen wij er slechts één liggen. Wij hadden drie corjalen en met een daarvan was een paar dagen te voren Rogalli met twee man vooruit gereisd naar Mombabasoe, om daar de noodige boschnegers en booten voor den terugtocht te huren. Wij vreesden, toen wij slechts één boot zagen liggen, dat de andere corjaal misschien door den sterken stroom was meegesleept en verloren gegaan, wat onze terugreis natuurlijk ernstig zou hebben belemmerd. Heden morgen is het water van de kreek echter sterk gedaald, meer dan een meter vergeleken met gisteravond, en gelukkig komt de verloren gewaande boot weer te voorschijn. $\mathrm{Zij}$ was te kort vastgebonden en door de sterke stijging van het water gezonken.

Alle beschikbare arbeiders worden naar K.M. 7.6 gestuurd, om de daar neergelegde vrachten af te halen. Wij gaan met een corjaal de Tawa-kreek af en de Toekoemoetoe een eindweegs op, onderweg botaniseerende in den plantengroei van de oevers. Veel nieuws treffen wij er echter niet aan. Interessant is hier een parasiet op de bamboe-stoelen, een Ascopolyporus, een Ascomyceet, die uiterlijk veel van een Polyporus heeft, van welken verscheidene soorten in Brazilië op bamboe worden gevonden. 
In den middag gaan wij naar den Apodanthes-boom langs het tracé, om hem om te kappen en te fotografeeren. Wij vinden van den parasiet een groote hoeveelheid uitgebloeide exemplaren, maar ook eenige open bloemen, die allen twijfel wegnemen of wij wel met een Rafflesiacea te maken hebben of niet. De boom is ongetwijfeld een Casearea, doch wij vinden alleen bloemkussens met verdroogde bloemen. Na eenig zoeken in de buurt, ook den volgenden dag, vinden wij nog eenige Casearea's, waaronder een tweede nauw-verwante soort, doch van deze soort vinden wij er geen, die door Apodanthes is aangetast maar wel van de eerste nog één met sporadische parasieten.

Terwijl wij nog bezig zijn met fotografeeren, hooren wij in de verte een schot en iets later komt Zaandam aan, eenigszins opgewonden, met de mededeeling, dat hij op het tracé bij K.M. 2 een grooten tijger heeft geschoten, die evenals hijzelf een kudde pingo's achtervolgde. Zaandam had den tijger opgemerkt, zonder dat deze hem zag en had hem onmiddellijk doodgeschoten. Wij gingen er heen en vonden het dier, zooals het was neergevallen, midden op het pad liggen, een groot, zwaar vrouwelijk exemplaar, dat door twee mannen met moeite kon worden gedragen.

23 Maart. De tijger wordt gevild en de schedel geprepareerd. De meeste arbeiders vrachten nog van K.M. 7.6 en verder wordt de dag in afwachting van de boschnegers van Mombabasoe met jagen en botaniseeren in de buurt van het kamp doorgebracht.

24 Maart. Heden moet Rogalli stellig met de menschen van Mombabasoe aankomen en wij beginnen in te pakken, blikken, die open zijn dicht te soldeeren en alles in gereedheid te brengen voor het vertrek. Tegen tien uur klinkt in de verte een schot en hooren wij stemmen en spoedig daarop verschijnen twee boschnegers met een corjaal aan den waterkant met de mededeeling, dat Rogalli hen spoedig zal volgen. Korten tijd later komt Rogalli inderdaad aanzetten, doch terwijl de eerstaangekomenen ons in alle gemoedsrust hadden verwelkomd, is Rogalli zichtbaar opgewonden en vertelt ontroerd, dat een minuut of tien tevoren, een paar honderd meters 
van het kamp af, de boschneger, die de corjaal, stuurde, waarin hijzelf was gezeten, plotseling over boord gevallen en niet meer is bovengekomen. De 2 djoeka's, die er reeds waren, sprongen dadelijk in hun bootje, om bij het opsporen van den verongelukte behulpzaam te zijn, en aangezien er reeds door een zestal djoeka's naar den man gezocht werd, was er voor ons in deze niets te doen dan afwachten, wat de uitkomst daarvan zijn zou. Na ruim een uur gezocht en gedoken te hebben, kwam het heele gezelschap terneergeslagen in het kamp terug met de mededeeling, dat hun landgenoot vermoedelijk op een diepe plaats door den sterken stroom onder een gezonken boomstam was geschoven en daar was blijven vastzitten, zoodat verder zoeken nutteloos was. Wij kwamen overeen, dat twee van de djoeka's met het kleinste bootje en eenige vracht naar Mombabasoe zouden vertrekken om de treurige tijding aan de familie-leden van den verdronkene over te brengen. Wij zelf zouden den volgenden dag met de overige menschen vertrekken. De stemming was door het ongeval natuurlijk zeer gedrukt en voor ons voegde $\mathrm{zich}$ bij het leedwezen over den armen kerel nog ongerustheid over de gevolgen, die zich,'in verband met de bijgeloovigheid van de boschnegers, uit dit ongeval zouden kunnen ontwikkelen.

Wij brengen alles voor het vertrek op den volgenden dag in gereedheid en de achtergebleven boschnegers trekken met treurige gezichten het bosch in, om na een tijdje terug te komen met kruiden die, in water gelegd waarin men baadt, mogelijk een voorbehoedmiddel zijn tegen verdere ongelukken.

25 Maart. Wij vertrekken om halfacht met twee boschnegerbooten en twee eigen corjalen. Wanneer wij de Tawa-kreek uitvaren en in de Toekoemoetoe komen, varen de beide boschnegerbooten een klein eindje de rivier op en alle boschnegers scheppen daar een petroleumblik vol water. Hetzelfde herhaalt zich als wij de Toekoemoetoe uitvaren en in de Boven-Saramacca komen; de boschnegers verklaren, dat zij dit doen, omdat zij niet mogen drinken van het water waarin nog het lijk van een hunner kameraden ligt. Er wordt vlug doorgevaren en reeds 
om 4 uur in den namiddag zijn wij op Mombabasoe.

Wij hadden onderweg nog niets bemerkt van de familie van den verongelukte, die ongetwijfeld de rivier zou opkomen om te trachten het lijk te vinden, wanneer dit zooals steeds bij drenkelingen voorkomt, na eenigen tijd zou komen bovendrijven. Daarover moest zeker nog een behoorlijke kroetoe (beraadslaging) gehouden worden.

Kort voordat wij op Mombabasoe aankwamen, vroeg de stuurman van onze boot, de boschneger Matthias, wanneer wij zouden doorreizen. Wij gaven te kennen, dat wij den volgenden dag, Zondag, te Mombabasoe zouden blijven, om den dag daarop, dus Maandag, naar beneden te vertrekken. Matthias antwoordde, dat 't dan in orde was en dat hijzelf met ons zou mede gaan. De opzichter Rogalli had namelijk te Mombabasoe een overeenkomst gesloten, dat 12 boschnegers ons onmiddellijk na aankomst aldaar tot beneden de vallen van de Saramacca zouden brengen en Matthias behoorde tot de gecontracteerde vaarders.

Nauwelijks echter zijn wij te Mombabasoe aangekomen of Matthias, klaarblijkelijk spoedig anders ingelicht, komt vertellen, dat hij niet meer met ons zou kunnen vertrekken en dat hij de boot, waarmede hij ons van de Tawakreek heeft gebracht, moest terug hebben, om weer naar de kreek terug te gaan om het lijk van den verdronken man te helpen zoeken. Ook de eigenaars van de andere booten waarmede wij waren aangekomen, kwamen hun vaartuig opeischen en op onze mededeeling, dat wij die booten toch noodig hadden om Maandag af te zakken, bleven zij zeer onhebbelijk aandringen, en uitten zelfs de bedreiging, dat zij, indien wij zelf onze lading niet uit de booten lieten halen, deze eenvoudig er uit zouden gooien en de booten mede nemen.

Tegen den boschopzichter Rogalli namen de boschnegers eveneens een zeer eigenaardige houding aan en hun achterdocht tegen hem werd nog scherper, toen hij in plaats van zich weinig van dien argwaan aan te trekken, niet zooals gewoonlijk zijn hangmat in een boschnegerkampje opsloeg, maar een afzonderlijk kampje aan den waterkant liet opzetten. Het was duidelijk, dat de pu- 
blieke opinie te Mombabasoe Rogalli aansprakelijk stelde voor den dood van Lambertus, den verdronken man. Het was in de oogen van de boschnegers hoogst verdacht, dat niemand wist hoe Lambertus op den bewusten morgen was overboord geslagen. Hij was alleen in de corjaal met Rogalli en den arbeider Donk en beide konden niet anders verklaren, dan dat zij op een gegeven oogenblik een schok voelden en toen zij zich omkeerden zagen, dat de man in het water was gevallen en niet meer boven kwam. De Hernhutter schoolmeester van het nabijgelegen dorpje Boschland verklaarde nog den dag van onze aankomst te Mombabasoe, dat Lambertus kort geleden van Kwakoegron was teruggekeerd met een groote voorraad dram, die hij stevig aansprak en dat hij wel eens aan toevallen leed. Het waarschijnlijkste kwam het ons dus voor dat hij een epileptischen aanval had gehad.

Er waren in het gedeelte van de rivier, waar Mombabasoe is gelegen, geen door het Gouvernement erkende hoofden. Wij lieten echter de door de bevolking erkende hoofden ontbieden, zekeren Kapitein Nicodemus van Boschland en Kiné, die als Granman van den geheelen stam werd beschouwd. Kiné, die nota bene een van de menschen was, die ons volgens overeenkomst de rivier zoude moeten af brengen, liet weten, dat hij niet kon komen, omdat hij ziek was en Nicodemus zeide, dat als al onze menschen weer de rivier op gingen, om het lijk te zoeken, hij ons niet aan ander personeel zou kunnen helpen, omdat er geen andere menschen in de buurt beschikbaar waren, een tastbare onwaarheid, want er wonen in de buurt over de 400 personen, en bij alle landingsplaatsen lagen talrijke booten, meer dan voldoende, om ons betrekkelijk klein gezelschap de rivier af te brengen.

In den nacht om twee uur hoorden wij Granman Kiné, niettegenstaande zijn z.g. ziekte, luidsprekend met nog een aantal boschnegers ons kamp voorbij gaan en met eenige corjalen de rivier op vertrekken.

Den volgenden morgen Zondag 26 Maart, bleek, dat wij ons te Mombabasoe vrijwel als onder arrest konden beschouwen. Wanneer wij niet door verscheidene boschne- 


\section{VERSLAG VAN EEN REIS NAAR DEN HENDRIKTOP}

gers tegelijkertijd werden lastig gevallen, om medicijnen kwam er telkens iemand gluren of wij er nog wel waren en de booten waarin wij nog lading hadden werden telkens, vaak op zeer onhebbelijken toon opgeëischt. Om niet tot grooter onbewegelijkheid te worden gedoemd, hielden wij er echter onze lading in. Den vorigen avond hadden wij reeds bezoek gehad van een bejaarde, zeer robuste boschnegerdame, Ma Maria geheeten, die zich aandiende als moeder van den overleden Lambertus. $\mathrm{Na}$ onze betuigingen van rouwbeklag te hebben in ontvangst genomen, achtte zij het nog noodig te bewijzen, dat zij de „werkelijke" moeder van Lambertus was, door haar kleedij op zijde te schuiven en te toonen, dat zij een band stijf om haar buik had gebonden, een bijzonder teeken van rouw van het lichaam, dat den verongelukte had gebaard. Al spoedig kwam echter de meer zakelijke kant van haar bezoek voor den dag. Lambertus had voor zijn dood toch nog een paar dagen ten onzen behoeve zijn corjaal de rivier opgepagaaid en het was billijk, dat nu hij geen kinderen had, dit loon aan zijne moeder zou worden uitbetaaid'. W'Wij konden veel' voor die redeneering voelen en spraken met Ma Maria af, dat wij den volgenden dag dit loon aan een door haar aan te wijzen boschneger zouden uitbetalen. Zijzelve zou als eenige vrouw met de expeditie ter opsporing van het lijk mede vertrekken.

In plaats van den vertegenwoordiger van Ma Maria kwamen Zondagmorgen evenwel twee onbekende boschnegers met een andere vrouw aanzetten met de bewering, dat niet Ma Maria, maar zij de moeder van den overledene was. Aan wie nu het geld uit te betalen? Zie daar een vraag voor een Salomo. Aniba, de gemachtigde van $\mathrm{Ma}$ Maria verscheen ook en van weerskanten werd met even groote hardnekkigheid volgehouden, dat de tegenpartij ons trachtte te bedriegen. Aangezien alleen Ma Maria den tocht naar de Tawa-kreek ondernomen had, zich dadelijk als moeder had aangediend en wij tenslotte het geld ook aan haar hadden beloofd, besloten wij dan ook het loon van Lambertus aan Aniba ter hand te stellen.

Een bezoek aan het naburige dorp Boschland, onge- 
veer een kilometer benedenstrooms van Mombabasoe gelegen en standplaats van den Hernhutter-zendeling Krolis bracht ons tot de overtuiging, dat wij daar veel prettiger zouden kunnen kampeeren, dan op Mombabasoe. Wij lieten dan ook de geladen booten door onze eigen arbeiders naar Boschland brengen.

Toen wijzelf ook op Boschland waren aangekomen, werden ons daar door verscheidene inwoners verhalen gedaan over de slechtheid van de menschen van Mombabasoe: Zoo werd ons verteld, dat er vroeger een voetpad was door het bosch, dat de twee dicht bij elkaar liggende dorpen verbond. Maar men liet dat pad weer dichtgroeien omdat de lui van Mombabasoe daarvan misbruik maakten voor nachtelijke bezoeken aan de vrouwen van de mannen van Boschland. In ieder geval gedroegen de menschen van Boschland zich, waarschijnlijk door het goede voorbeeld van den schoolmeester, den heer Krolis, heel wat beschaafder dan de brutale en luidruchtige bende op Mombabasoe.

Wat het aanwerven betreft van menschen om ons de rivier af te brengen was men te Boschland echter volkomen solidair met Mombabasoe en weldra gaf kapitein Nicodemus van Boschland dan ook toe, dat men onderling afgesproken had, om de geheele expeditie niet af te brengen tot dat Granman Kiné met zijn menschen van de Tawa-kreek terug was. Tot zoolang was de rivier voor ons afgesloten.

Volgens opgave van den opzichter Rogalli moeten er ook chicle-boomen voorkomen in de buurt van Mombabasoe dicht bij een grondje van Ma Maria. Op Maandag morgen toen er toch geen kans was, om de rivier af te zakken gingen wij daarheen, troffen daar inderdaad talrijke boomen aan van dezelfde soort als wij bij K.M. 16 hadden afgetapt en lieten door onze arbeiders een zoo groot mogelijke hoeveelheid melksap van deze boomen aftappen. Wij waren hier ook zoo gelukkig, om een boom met rijpe vruchten aan te treffen, waarvan er te Paramaribo later echter slechts twee pitten ontkiemden.

In den middag weer te Boschland teruggekeerd, besloten wij kapitein Nicodemus thans het vuur nog wat nader aan de schenen te leggen. Wij zeiden hem in tegen- 
woordigheid van den heer Krolis, thans niet meer te vragen of te verzoeken of hij ons kon helpen aan booten en menschen, om daarmede de rivier af te zakken, doch gelastten hem in naam van den Gouverneur, om te zorgen, dat wij den volgenden morgen om zeven uur met al het personeel en al de andere menschen de rivier af konden gaan. Wij zeiden hem, dat wij niet onbepaalden tijd konden blijven wachten, omdat onze voeding opraakte en dat hij als kapitein verplicht was, om ambtenaren van het Gouvernement bij reizen in het binnenland behulpzaam te zijn. Nicodemus kreeg het zichtbaar benauwd, gaf ten slotte toe, dat de boschnegers verkeerd hadden gedaan, om de bewuste afspraak te maken, mààr, zeide hij, als hijdan toch onaangenaamheden moest krijgen, kreeg hij die liever met het Gouvernement in Paramaribo, twaalf dagreizen van hem af, dan met zijn allernaaste buren!

Dinsdagmorgen komt Nicodemus zeer deemoedig vertellen, dat hij persoonlijk wel bereid is, om ons de rivier af te helpen, maar dat hij werkelijk niemand kan vinden, om met hem mee te gaan en alleen kan hij natuurlijk niet een boot over de vallen brengen. Op de mededeeling, dat wij wel iemand hebben (boschwachter Dalger), die zeer goed een boot door de soela's kan brengen, als hij maar den weg wijst, antwoordt Nicodemus, dat hij een zoo verantwoordelijk werk alleen met een landgenoot aandurft. Wij togen dus weer aan het aftappen van chicle-boomen bij het grondje van Ma Maria en deden verder alleen nog een poging, om door bemiddeling van zekeren Simson, een boschneger van Pakka-pakka, die ons naar boven had gebracht, en die in gezelschap van Lampoe, ook een onzer oude vrienden een bezoek was komen brengen op Mariakriki, iets beneden Boschland, waar hij zijn bovenlandsche echtgenoote had zitten - een ploeg vrachtvaarders van zijn dorp te bestellen. Simson was ten zeerste verontwaardigd over de wijze, waarop wij door Granman Kiné en de menschen van de buurt behandeld waren en sprak af den volgenden morgen naar Pakka-pakka te zullen vertrekken, om zoo vlug mogelijk met de noodige booten terug te keeren.

Men zal zich wellicht afvragen, waarom wij geen po- 
gingen deden, om zonder boschnegers de rivier af te varen, doch voor vervoer van al ons personeel en de geheele bagage hadden wij in de eerste plaats niet voldoende booten, zelfs al hielden wij de door de boschnegers opgeëischte booten nog in gebruik, en ten tweede is het afvaren van de groote stroomversnellingen zonder een goede gids, zeer gevaarlijk, veel gevaarlijker nog, dan het opvaren. Ook de heer Van Stockum heeft deze vallen, hoewel hij er zonder boschnegers op was gekomen, met een boschneger-loods moeten afvaren.

Om duidelijk te doen uitkomen, dat wij door de boschnegers van de omgeving van Mombabasoe a.h.w. werden vastgehouden, gaven wij ten slotte ook toe aan hun eisch om de van hen in gebruik gehouden booten terug te geven Dit geschiedde onder de uitdrukkelijke mededeeling, dat alle met hen gesloten overeenkomsten nu ook als vervallen werden beschouwd en de geheele verantwoordelijkheid voor ons oponthoud voor rekening van Granman Kiné en henzelf zou komen.

Woensdag morgen ontvangen wij in de vroegte een mededeeling van Simson, dat hij niet volgens afspraak naar beneden is vertrokken, omdat hij een boodschap van Granman Kiné heeft ontvangen, dat hij zich niet met de zaak moest inlaten, omdat hij, Kiné zelf wel voor het vervoer van de „,bakra's zou zorgen. Spoedig daarna krijgen wij een boodschap van den grooten man zelven, dat hij ons later op den dag hoopt te komen opzoeken; hij is in den nacht met het geheele gezelschap van de Tawakreek teruggekeerd en heeft het lijk van Lambertus gevonden en begraven.

Wij antwoorden, dat wij Kiné zoo spoedig mogelijk verwachten te zien en dat wij erg boos op hem zijn en bij den Gouverneur in de stad zullen aanklagen, wegens afsluiting van de rivier voor landsdienaren.

Kiné komt desniettegenstaande pas om 10 uur aanzetten, uitgedoscht in een oude korporaalsjas, die hij klaarblijkelijk niet bij zich had, maar eerst had laten halen uit zijn woning beneden aan de rivier, met een klein bootje, dat pijlsnel Boschland was voorbij gevaren. Zijn stemming was zeer gedrukt. $Z$ ij waren in den beginne zoo erg in hun 
schik geweest, die bakra's eens hun macht te kunnen laten voelen. Maar nu kwamen zij, door kapitein Nicodemus en den schoolmeester voorbereid, bewust van hun schuld.

Granman Kiné begon met te zeggen, dat hij door den ongelukkigen dood van Lambertus tot zijn spijt verhinderd was, om dadelijk gevolg te geven aan zijn overeenkomst, om ons de rivier af te brengen, maar dat hij nu bereid was, om den volgenden morgen zoo vroeg mogelijk te vertrekken.

Wij antwoorden heel kort te kunnen zijn. Een afspraak met hen wegens ons vervoer bestond niet meer; die was van de zijde der boschnegers, getuige het terugeischen van de booten, eenzijdig verbroken. De rivier was op last van hem, Kiné, voor ons gesloten. Wij hadden geen booten genoeg, omdat wij gerekend hadden op de hulp van de boschnegers, die ons schandelijk hadden teleurgesteld; onze voeding raakte op; wij verloren tijd en het Gouvernement verloor onnoodig arbeidsloon en verblijfkosten door ons langer verblijf in de bovenlanden. Dat had Kiné alles van te voren goed moeten overleggen, alles kwam nu voor zijn verantwoording. Wilde hij de rivier nog langer afgesloten houden, dan kon hij dat doen, afspraken maakten wij nu niet meer, wij gelastten alleen, evenals aan $\mathrm{Ni}$ codemus, in naam van den Gouverneur, om zoo spoedig mogelijk het reisgezelschap de rivier af te brengen. Over de geheele zaak zou rapport uitgebracht worden aan den Gouverneur en Zijne Excellentie zou dan over alles hebben te beslissen, zoowel over de betaling voor het vervoer, als over de straf, die zij voor het ongerechtvaardigde oponthoud van de expeditie zouden hebben te ontvangen.

Daarmede beschouwden wij het onderhoud afgeloopen en gingen weer naar het grondje van Ma Maria, om daar in de buurt chicle af te tappen.

In den middag kwam er een deputatie van den Granman en de kapiteins zeer deemoedig bij ons kamp, om schuld te bekennen en vergiffenis te vragen. $\mathrm{Zij}$ erkenden verkeerd te hebben gedaan, door niet te zorgen, dat een gedeelte van de menschen de bakra's verder zouden vervoeren, terwijl een ander gedeelte het lijk van den verdronkene ging opsporen. Maar daaraan hadden zij niet 
gedacht. Ook beweerden zij, dat zoolang het lijk niet opgevischt was, zij niet van het water van de rivier hadden mogen drinken; en hoe hadden zij ons dan dagen lang de rivier kunnen afvaren?

Wij antwoordden op het laatste, dat zij dan toch net zooals bij den terugtocht van de Tawa-kreek gedaan hadden, water uit zijrivieren of kreeken hadden kunnen gebruiken; en dat het ernstigste van de heele geschiedenis was, dat de rivier voor ons was afgesloten, en dat zij een onderlinge afspraak hadden gemaakt, om ons niet de rivier af te brengen alvorens de expeditie van de Tawakreek was teruggekeerd. Maar napraten hielp nu niet meer; wij zouden afwachten, wat er nu verder zou gebeuren. Met de belofte, dat wij den volgenden morgen vroeg zouden kunnen vertrekken gingen de hooge autoriteiten met bedrukte gezichten uiteen.

Den 30sten Maart, eindelijk, was de dag van ons vertrek gekomen en in den vroegen morgen verscheen Granman Kiné met 8 booten en 17 boschnegers, om alle bagage in te laden. De overeenkomst voor de reis was oorspronkelijk gesloten voor zes booten en 12 man en deze zouden zeer zeker ook voldoende geweest zijn, om alles te vervoeren. Maar Kiné scheen er op te vlassen, dat hij meer loon zou kunnen krijgen als hij meer menschen aan het werk zette.

Behalve een enkele opmerking, dat zes booten wel voldoende geweest zouden zijn, lieten wij ons echter heelemaal niet met de regeling van het vervoer in.

Toen een boschneger iets over de betaling wilde vragen, werd hij naar Granman Kiné verwezen, met de opmerking, dat hij het maar met zijn ondergeschikten moest regelen. Hij had de bakra's opgehouden, dus moest hij nu ook zorgen, dat zij weer thuis kwamen.

Een van ons had op Maripa-kriki, een boschnegerdorpje in de buurt, een aardige kleine corjaal gekocht, om die naar Paramaribo mede te nemen. Maar het bootje was zoo klein, dat het in het geheel geen lading kon bevatten en om afzonderlijk daarvoor boschnegers in dienst te nemen, zou natuurlijk veel te duur uitkomen. Onze beide Indianen, Banga en Louis bleken gelukkig spoedig 
bereid, om het bootje door onze boschnegers spoedig „mooi oema” (mooie vrouw) genoemd, naar beneden te brengen en vonden het, echt Indiaansch, prettig, om in dit notedopje geheel hun eigen baas te zijn. Later in de vallen volgden zij steeds in 't zog van een der boschnegerbooten; en behalve één keer, dat het bootje vol water liep, en zij er haastig moesten uitspringen, om er niet mee om te slaan, liep alles zonder ongelukken af. Wij moeten hier echter bijvoegen, dat wanneer de soela's hun te bar werden, zij het lichte bootje over de rotsen trokken.

Voordat wij de reeks groote vallen afzakten moesten wij nog even aanleggen op het dorp van Granman Kiné, Granmankondre. Hier waren nog verscheidene teekenen van den heidenschen afgodsdienst, die blijk gaven, dat er zich hier in afwijking van de overige dorpen aan de Boven-Saramacca slechts weinig christelijke boschnegers bevonden. Kiné, gevraagd of hij ook nog heiden was, gaf zichtbare teekenen van verlegenheid en zeide, dat hij weliswaar nog heiden was, maar druk bezig, om ,,voor christen te studeeren", denkende aldus bij ons in een goed blaadje te komen. Later vernamen wij, dat het grootste bezwaar voor Kiné was, dat hij er meerdere vrouwen op nahield. Om aangenomen te kunnen worden, moest een nieuw lidmaat zich niet aan polygamie schuldig maken.

Spoedig na het verlaten van Granmankondre begon de afvaart door de watervallen, eerst Atereboto, vervolgens Dikifakka, Sopoe en Grandam. Voor den Grandam moesten wij uitstappen en liepen met onze arbeiders en Granman Kiné langs den linkeroever ongeveer een kwartier door het bosch tot aan den voet van den grooten val. Daar stonden wij het schouwspel van het brengen van de booten over deze imposante stroomversnelling aan te zien samen met Granman Kiné, die van zijn strategisch punt op een hooge rots het afzakken met werkelijk veel beleid commandeerde. De meeste booten werden langzaam langs zijgeultjes naar beneden gevierd, de grootere gingen langs den kant van den hoofdval. De grootste booten hadden echter ook daarvoor te veel diepgang, zoodat zij op een bepaald punt midden in den val moesten worden 
losgelaten, om dan door twee boschnegers - die er op het juiste oogenblik insprongen - midden door den bruisenden cataract met fabelachtige handigheid tusschen de rotsen te worden doorgevoerd.

Wittiston en Wedebon werden gemakkelijk genomen; soms moest er langs de rotsen gevierd worden, maar meestal ging het in het midden van de versnelling in het diepste water pijlsnel naar beneden. Kiné, die onze boot stuurde en zag hoe wij van deze watersport genoten, greep onmiddellijk het goede moment aan om te vragen, of wij hem het gebeurde toch niet zoo erg kwalijk wilden nemen en of we op zijn tijd een goed woordje voor hem wilden doen bij den „Granman in de stad”.

$\mathrm{Na}$ nog een paar vallen, Grassi en Jakakalbasi afgeschoten te zijn, kwamen wij aan den mooisten, den Brokobotoval. Opgaande hadden wij dezen val door een zijkreekje om omgaan, maar nu zakten wij den hoofdstroom af. Wij waren in een van de laatste booten. De zes, ons voorgaande booten verdwenen de een na de ander als bij tooverslag onder het gladde watervlak boven den val, zoodat zelfs niet eens de hoofden van de bemanning meer zichtbaar waren. Spoedig waren ook wij aan de beurt. De corjaal voer eerst recht vooruit, met de kop in de vrije ruimte, om dan met een klap naar beneden te vallen en de soela af te snellen.

Nog een paar kleinere valletjes en wij stoppen bij eenige bekenden van Pakka-pakka, die op hun ,"buiten”, hun grondje, logeerden. Het gebeurde met de bakra's werd natuurlijk breed uitgesponnen en onze boschnegers wilden hier blijven overnachten, om de zaak nog eens van alle kanten met hun kennissen te bekijken. Maar wij wenschten door te gaan naar Pakka-pakka, waar wij om halfzes aankwamen.

Wij overnachten weer in het leegstaande huis van den meester en gingen den volgenden dag door tot Kwattahede. Onderweg stopten wij even bij een grondje van zekeren Obermuller, een Demerariaanschen kleurling, die in dienst van een balata-onderneming gedurende het seizoen als bleeder werkte en het overige gedeelte van het 


\section{VERSLAG VAN EEN REIS NAAR DEN HENDRIKTOP}

jaar in het bosch bleef, en daar moederzielig alleen, den landbouw uitoefende. Hij had een zestal jaren geleden een grondje, door boschnegers aangelegd, maar verlaten wegens het geweldig groote aantal parasol-mieren, van hen overgenomen en was begonnen met de mieren krachtig te bestrijden, op een zeer primitieve en omslachtige, maar blijkens de uitkomst afdoende wijze. Het grondje lag op een flauwe glooiïng tegen een kleinen heuvel aan en door een dikwijls meterdiep stel kronkelende slooten ving Obermuller het regenwater van den heuvel op en leidde dit naar de mierennesten,waaromheen hij een diepe trens groef. Bij regen liepen de nesten zoodoende geheel onder water en werden daardoor vernietigd. Er ontstonden echter toch voortdurend nieuwe nesten en de strijd moest telkens worden hervat. Toen wij op zijn grondje kwamen hadden wij juist de gelegenheid, pas aangelegde trenzen te bezichtigen en geloofden gaarne, dat hij meer werk had met de bestrijding van de mieren, dan met al zijn overig werk bij elkaar gerekend.

Ook de grond zelf was tot in alle onderdeelen netjes onderhouden en het was zeer opmerkelijk, dat waar de boschnegers elk jaar een nieuw stuk bosch kappen en een nieuw grondje aanleggen, dikwijls op grooten afstand van dat van het vorig jaar,Obermuller denzelfden grondgedurende zes jaar onafgebroken in cultuur gehouden heeft. Hij past hier een soort wisselbouw toe, door op de plaatsen waar hij het vorige jaar cassave had geplant, suikerriet en bananen te teelen.Opdie gedeelten had hijwat onkruid;zijn cassaveaanplanting was evenwel volkomen vrij van wied.

Onze boschnegers, die ook vol belangstelling het grondje van Big Body (grooten broer), zooals zij onzen vriend noemden, in oogenschouw namen, kregen natuurlijk de opmerking te hooren, dat dit nu eens de goede manier was, om een grondje aan te leggen, en den raad, dat zij het ook op dezelfde wijze moesten doen. Zij gaven evenwel ten antwoord, dat het voortdurend wieden veel te vermoeiend was en dat zij daar maar pijn in hun rug van zouden krijgen door het lange bukken. Zij kapten dan veel liever elk jaar een nieuw stuk bosch om. Met de bijl 
de reuzen van het oerwoud te vellen, lachte hen veel meer toe, dan het kleinzielig wieden van een oud grondje.

Iets over drieën kwamen wij op Kwattahede aan, waar wij thans den onderwijzer, den heer Nelson aantroffen en ons kamp opsloegen onder zijn huis. Den volgenden dag wilden wij een „kroetoe” houden over houtzaken en daarvoor moesten nog verschillende boodschappen naar de omwonende kapiteins gezonden worden.

1 April. Om acht uur begint de raadsvergadering op een pleintje tusschen een paar boschnegerwoningen en zooals op alle kroetoe's wordt er tot in het oneindige over de zaak geboomd. De heer Nelson, die fluks heeft begrepen, wat de hoofdzaak is, vertaalt de bedoeling van „lanti" (het Gouvernement) met groot talent in de beeldrijke, kinderlijk opgeschroefde taal van de boschnegers en na een paar uur geredeneerd te hebben, meenen wij werkelijk zoo ver te zijn, dat er een eind aan gemaakt kan worden. Het is onderstusschen ook knapjes warm geworden en wij zijn blij, als wij om elf uur kunnen vertrekken. Wij hebben weer eenige kleine valletjes en ten slotte de Mamadam bij Jacobkondre af te varen en komen om halfvier bij het magazijn van de Balata Compagnie Suriname aan.

Den volgenden morgen vroeg vertrekken wij naar Kwakoegron. Bij gelegenheid van de „kroetoe” gisteren bleek, dat Granman Kiné en zijn menschen het wilden doen voorkomen alsof zij ingevolge de oorspronkelijk door Rogalli met hen gesloten overeenkomst ons alleen tot het Balata magazijn bij Jacobkondre hadden te brengen. Wij merkten echter dadelijk op, dat uitdrukkelijk gezegd was, dat die oude overeenkomst door hen verbroken en dus vervallen was, en dat afgesproken werd, dat alles aan den Gouverneur gerapporteerd zou worden, die ook beslissen zou over de betaling, die zij voor het afbrengen van de expeditie zouden krijgen. Het sprak dus vanzelf, dat zij ons naar Kwakoegron moesten brengen, waar een telefoon was en van waaruit dus het gevoelen van den Gouverneur kon worden verzocht. De heeren hadden klaarblijkelijk niet zoo ver doorgedacht en vonden het naderen van Paramaribo steeds bedenkelijker worden. 


\section{VERSLAG VAN EEN REIS NAAR DEN HENDRIKTOP}

Op Jacobkondre vroegen alle boschnegers verlof naar de op een half uur afstand gelegen dorpen van hun stamgenooten te gaan, om daar te overnachten. Een oogenblik bespraken wij of het wel geraden was, dit verlof toe te staan met het oog op de kans, dat onze vrienden van de gelegenheid zouden gebruik maken, om er van door te gaan. Maar wij meenden er nu zoo goed den wind onder te hebben, dat wij daar geen vrees voor behoefden te koesteren en werkelijk kwamen zij den volgenden dag ons stipt op tijd afhalen. De stemming gedurende de vaart naar Kwakoegron was echter zeer gedrukt. Telkens werd verzocht, om toch vooral aan den Granman te zeggen hoe mooi ze de vallen met ons waren afgezakt, en ze niet te hard te behandelen, zij wilden liever afgeranseld worden, dan in de gevangenis gestopt.

Uit een paedagogisch oogpunt vonden wij het wenschelijk ze op dit laatste punt niet te veel gerust te stellen; wij bepaalden ons dus tot de mededeeling, dat de Gouverneur een streng, maar ook stipt rechtvaardig man was.

Dienzelfden dag, Zondagmiddag om vijf uur, waren wij op Kwakoegron. Nauwelijks waren wij aan wal gestapt, of een van de jongste boschnegers stapte op ons toe, om ons in goed Hollandsch te begroeten. Gedurende de geheele reis had hij zich van den domme gehouden en was met zijn corjaal voortdurend in onze nabijheid geweest klaarblijkelijk met de bedoeling, om af te luisteren, wat wij met elkaar bespraken.

Onmiddellijk werd naar Paramaribo getelefoneerd, om onze aankomst te melden en stelden wij ons in verbinding met den Gouvernements Secretaris, belast met het toezicht op de boschnegers, om door zijne tusschenkomst de beslissing van den Gouverneur in te winnen. Deze was, doordat genoemde ambtenaar toevallig bij Zijne Excellentie was, spoedig verkregen en luidde, dat Granman Kiné en de kapiteins, die hij bij zich had, met ons moesten mede komen naar Paramaribo, om zich bij den Gouverneur over het gebeurde te verantwoorden.

Wij noodigden den Commandant van de Politie te Kwakoegron met twee zijner beambten uit, om bij de 
overbrenging van het bevel van den Gouverneur aan Kiné tegenwoordig te zijn, en de onbeschrijfelijke verbijstering, die zich bij het hooren van de boodschap op zijn gelaat en dat zijner kapiteins verbreidde, was zoo potsierlijk, dat het ons werkelijk alle moeite kostte, om den noodigen ernst te bewaren. Een kostelijk moment volgde nog toen uitgemaakt moest worden, wie er als „kapitein” beschouwd moest worden. Zekere Andreas, die als „,bigi soema", groote man, veel invloed op Granman Kiné had, zag zich geplaatst tusschen zijn ijdelheid, om als gelijke van de kapiteins door te gaan en zijn vrees voor wat hen te Paramaribo wachtte. Wij merkten al spoedig, dat de andere kapiteins hem wel graag mede hadden; hij was ook werkelijk de krachtigste figuur. Met een zucht, die zeer verschillende gevoelens vertolkte, schikte hij zich bij het groepje, dat naar Paramaribo mede moest, toen wij eindelijk den knoop voor hem doorhakten en zeiden, dat hij zich maar als gelijke van de kapiteins moest beschouwen.

Het trof toevallig, dat den volgenden morgen om zes uur een leege ballast trein van Kwakoegron naar Zanderij I moest. Wij verkregen van den Directeur van Openbare Werken vergunning, om met dezen trein door te rijden tot Republiek, waar wij na een half uur wachten aansluiting kregen naar Paramaribo, dat wij om twaalf uur Maandag middag 3 April bereikten.

Hiermede was onze reis afgeloopen. Onze boschnegers kwamen er nogal genadig af. Van het loon, dat hun volgens de oorspronkelijk met hen gesloten overeenkomst voor de afvaart zou toekomen, werd afgetrokken, wat het gedwongen oponthoud aan meerdere kosten had veroorzaakt. Deze „boete” betaalden zij zonder morren. Veel meer indruk had op hen gemaakt, het feit, dat zij wegens de overtreding van de met hen gesloten overeenkomst, om ten alle tijde Gouvernements-ambtenaren langs de rivier te vervoeren, naar Paramaribo hadden moeten komen en vooral de plechtige zitting ten Gouvernements huize, waar de Gouverneur hen het ongepaste van hun handelwijze ernstig onder het oog had gebracht. 


\section{VERSLAG VAN EEN REIS NAAR DEN HENDRIKTOP}

\section{METEOROLOGISCHE WAARNEMINGEN}

Gedurende de reis werden zoo veel mogelijk meteorologische gegevens verzameld. Voor de waarnemingen van den luchtdruk, werden geregeld 4 aneroïd-barometers afgelezen. Twee van deze instrumenten vertoonden echter zoo groote sprongsgewijze afwijkingen, dat hunne gegevens niet konden verwerkt worden. De andere twee barometers, die met den kwikbarometer te Paramaribo gedurende 8 dagen waren vergeleken, werkten bevredigend.

Voor de temperatuur en vochtigheids-waarnemingen diende de aspirationspsychrometer van Assmann, die zeer betrouwbare gegevens levert.

De water-temperaturen werden met een thermometer opgenomen, die in $\frac{1}{2}$ graden is ingedeeld.

Bewolking en windkracht werden op de gebruikelijke wijze geschat.

Verder werden een barograaf en thermograaf medegenomen.

Helaas konden de waarnemingen vooral in het gebergte niet geregeld 3 maal daags worden opgenomen, deels omdat wij meestal over dag op reis waren, deels omdat wij bij het verhuizen dikwijls de instrumenten, die vrij zwaar waren, $1-2$ dagen vóor ons vertrek moesten wegzenden, daar voor den verhuisdag telkens slechts de allernoodzaakelijkste persoonlijke bagage mocht overblijven, om alles in eens te kunnen vrachten.

TEMPERATUUR-WAARNEMINGEN OP DE REIS NAAR DEN HENDRIKTOP 11 Februari-26 Maart 1922.

\begin{tabular}{|c|c|c|c|c|c|c|c|c|c|c|c|c|c|}
\hline \multirow{2}{*}{\multicolumn{3}{|c|}{ Datum. }} & \multirow{2}{*}{\multicolumn{3}{|c|}{ Plaats. }} & \multicolumn{3}{|c|}{\begin{tabular}{|c|} 
Temperatuur \\
graden Cel- \\
sius
\end{tabular}} & \multicolumn{2}{|c|}{\begin{tabular}{|c|} 
Betrek- \\
kelijke \\
vochtig- \\
heid \\
proc.
\end{tabular}} & \multicolumn{3}{|c|}{$\begin{array}{l}\text { Temperatuur } \\
\text { van het } \\
\text { rivierwater }\end{array}$} \\
\hline & & & & & & $\begin{array}{ll}8 & \mathrm{u} \\
\mathrm{vm}\end{array}$ & $\begin{array}{ll}2 & \text { u. } \\
\mathrm{nm} .\end{array}$ & $\begin{array}{l}6 \mathrm{u} . \\
\text { sav. }\end{array}$ & & & & & \\
\hline $11 \mathrm{~F}$ & ebr. & 22 & $\mid \begin{array}{l}\text { Toeboeka . . . } \\
\text { Mamadam . . } \\
\text { Njoekondre. . . }\end{array}$ & 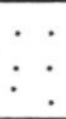 & & 23.0 & 27.1 & 27.2 & 88 & 73 & 26.1 & 27.1 & 26.8 \\
\hline 12 & $"$ & 22 & $\begin{array}{l}\text { Njoekondre . . } \\
\text { Heidoti . . . . } \\
\text { Kwattahede . . }\end{array}$ & $\begin{array}{l}. \\
. \\
. \\
.\end{array}$ & & 22.0 & 27.4 & 26.7 & 93 & 73 & $\overline{26.2}$ & 26.9 & \\
\hline 13 & $"$ & 22 & $\begin{array}{l}\text { Kwattahede . . } \\
\text { Makajapingo. . } \\
\text { Toekoesi . . . }\end{array}$ & $\begin{array}{l}. \\
. \\
. \\
.\end{array}$ & & 22.0 & 27.2 & 25.5 & 57 & 90 & $\overline{25.5}$ & 26.1 & 26.3 \\
\hline 14 & $"$ & 22 & $\begin{array}{l}\text { Toekoesi } \\
\text { Batoko planga } \\
\text { Pakka-Pakka }\end{array}$ & $\begin{array}{l}. \\
\dot{.} \\
.\end{array}$ & & 22.8 & 26.6 & 26.6 & $\overline{92}$, & 75 & $\overline{25.7}$ & 26.1 & 26.1 \\
\hline 15 & $"$ & 22 & $\begin{array}{l}\text { Pakka-Pakka } \\
\text { Brokoboto-val } \\
\text { Jakakalbasi-val. }\end{array}$ & $\begin{array}{l}. \dot{ } \\
. \\
.\end{array}$ & & $\overline{22.5}$ & & & $\overline{83}$ & & $\overline{25.2}$ & 26.0 & 26.2 \\
\hline
\end{tabular}


VERSLAG VAN EEN REIS NAAR DEN HENDRIKTOP 149

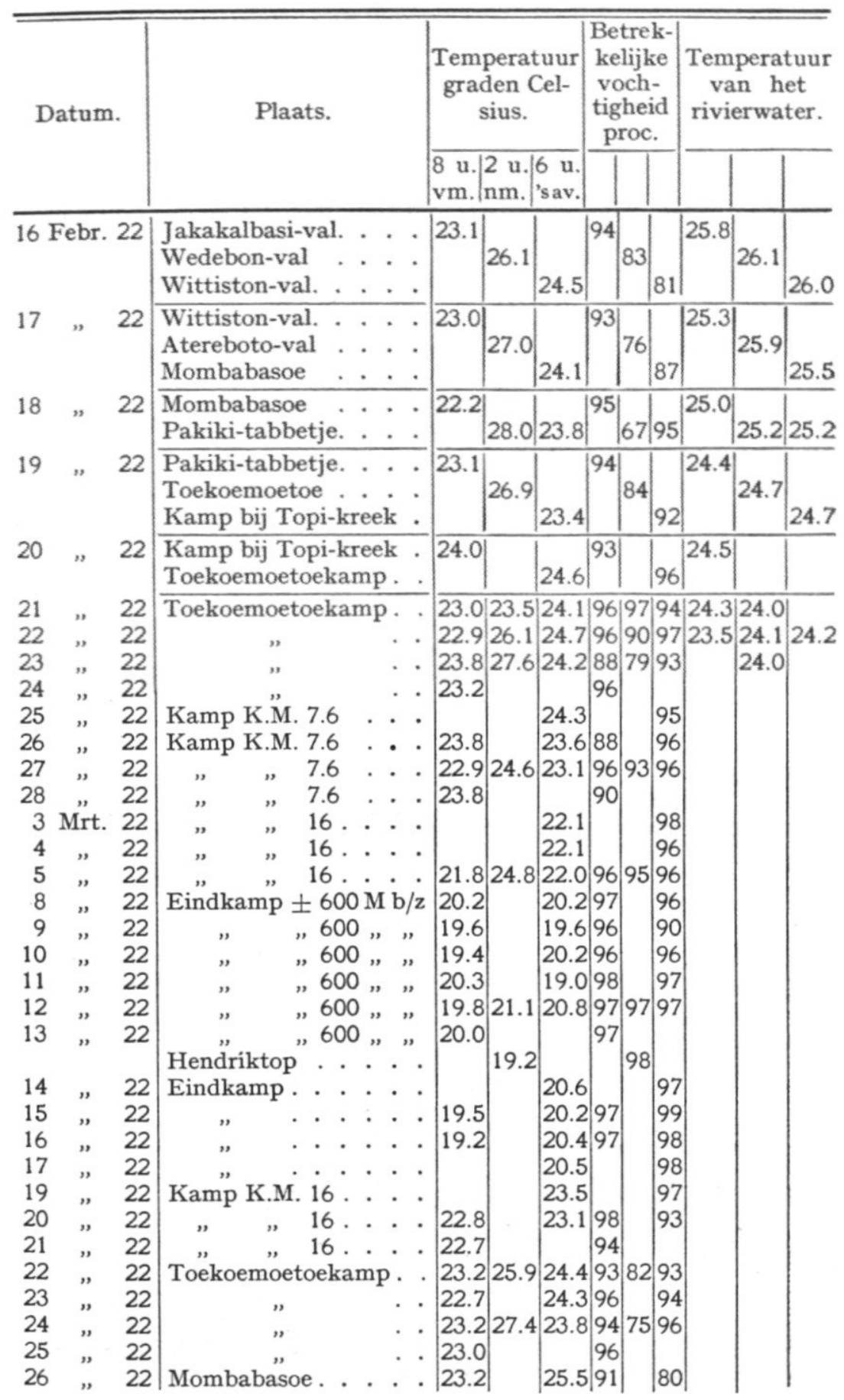


150 VERSLAG VAN EEN REIS NAAR DEN HENDRIKTOP

WAARNEMINGEN VAN DE TEMPERATUUR IN HET EINDKAMP $\pm 600 \mathrm{M} \cdot \mathrm{b} / \mathrm{z}$.

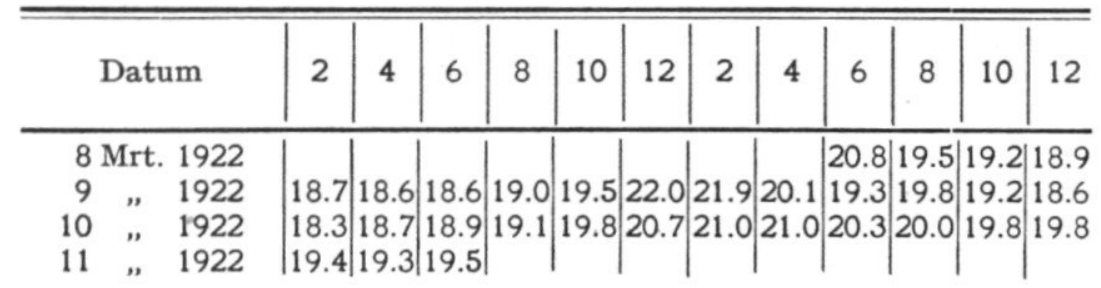

WAARNEMINGEN VAN DE LUCHTDRUKKING IN HET EINDKAMP $\pm 600 \mathrm{M} . \mathrm{b} / \mathrm{z}$.

\begin{tabular}{|c|c|c|c|c|c|c|c|c|c|c|c|c|}
\hline Datum & 2 & 4 & 6 & 8 & 10 & 12 & 2 & 4 & 6 & 8 & 10 & 12 \\
\hline $\begin{array}{r}8 \text { Mrt. } 1922 \\
9 \quad " 1922\end{array}$ & 708.8 & 708.6 & & & & & & & & & & $\begin{array}{l}709.5 \\
709.6\end{array}$ \\
\hline $\begin{array}{lll}10 & 1922 \\
11 & 1922\end{array}$ & $\begin{array}{l}709.0 \\
708.8\end{array}$ & $\begin{array}{l}708.6 \\
708.4\end{array}$ & $\left|\begin{array}{l}708.8 \\
708.3\end{array}\right|$ & & $|710.0|$ & 709.6 & 708.6 & $|707.6| ?$ & 707.5 & 707. & 708.7 & 709.2 \\
\hline
\end{tabular}

WAARNEMINGEN VAN DE TEMPERATUUR OP DEN HENDRIKTOP $1080 \mathrm{M}$. b/z.

\begin{tabular}{|c|c|c|c|c|c|c|c|c|c|c|c|c|c|}
\hline & Datum & 2 & 4 & 6 & 8 & 10 & 12 & 2 & 4 & 6 & 8 & 10 & 12 \\
\hline $13 \mathrm{~N}$ & Mrt. 1922 & & & & & & & 19.5 & 19.0 & 18.3 & 18.4 & 18.0 & 17.0 \\
\hline 14 & $\# 192$ & 16.2 & 16.2 & 16.6 & 17.0 & $|17.7|_{1}$ & 18.5 & & 19.0 & 18.1 & 16.9 & 16. & 16 \\
\hline 15 & 192. & 16.0 & 16.0 & 16.0 & 16.2 & $|16.6|$ & 17.0 & 19.0 & 18.5 & 17.0 & 17.0 & 16.8 & 16. \\
\hline & 1922 & 15.9 & 15.8 & 15.6 & & 16.01 & 17.8 & 19.0 & 17.6 & 17.4 & 17.4 & 17.4 & 16 \\
\hline 17 & " 1922 & 15.8 & 15.9 & 16.0 & 16.0 & $16.2 \mid 1$ & 18.6 & 19.5 & 20.9 & 17.0 & 17.0 & 17.1 & 16.9 \\
\hline 18 & 1922 & 15.9 & 156 & & & $\left.16.1\right|_{1}$ & 18.2 & 20.0 & 22.8 & & & & \\
\hline
\end{tabular}

WAARNEMINGEN VAN DE LUCHTDRUKKING OP DEN HENDRIKTOP $1080 \mathrm{M} . \mathrm{b} / \mathrm{z}$.

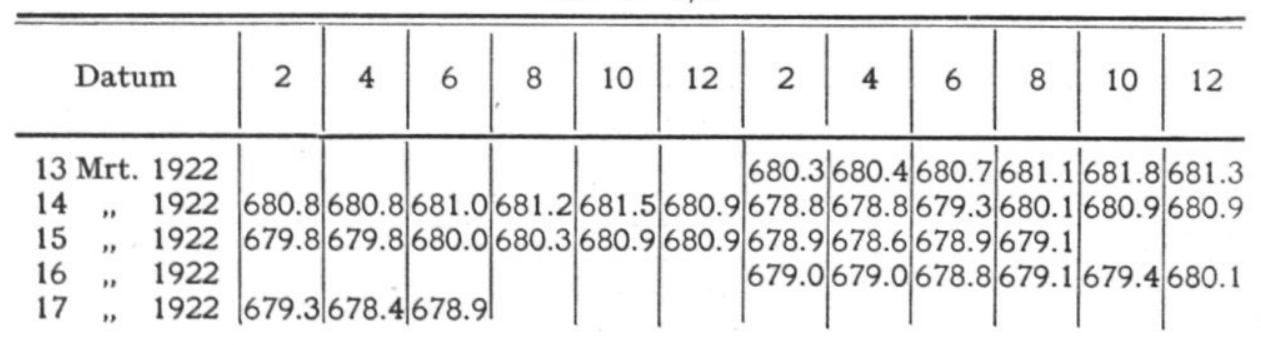

